\title{
TO MY FATHER
}

\author{
Postcard from the edge.
}

\section{BY DAVID G. BLAKE}

Interstellar uplink successful: 20-minute propagation delay.

This is farewell.

From your office window, I can see the colony's artificial biosphere disintegrating, fiery fragments crumbling free and bursting into showers of gold sparks. Across the broken horizon, prismatic tendrils of gas and dust bleed through the cracks, producing an array of writhing colours that span the optical spectrum. The result is remarkable.

The expanding cloud of spores, which reeks of mildew and decay, is not as impressive as the deluge of gold sparks, nor as striking as the rainbow weaves, but it is as exceptional in its own destructive way. It also shrouds the bodies that litter the streets below, although the memories of their faces warped with agony cannot be interred.

Unimpeded, plasmoids will spread those foulsmelling spores throughout the heliosphere. I recommend an immediate systemwide purge, followed by comprehensive tests to confirm the eradication of the radiotrophic fungi. It will do nothing for the colony, and even less for those of us left behind, but it should prevent such a disaster from recurring.

I am ... relieved that you made it out before it was too late.

The bookshelf behind your desk still holds many of your favourite books: a few flawlessly positioned, as if nothing had changed; some crooked or upturned; others spilled out over the cold floor. You emptied the locked desk drawer - and the wall safe behind the painting of a sunset on Mars - but left the others filled with things not deemed significant enough to take. You even left behind the bottle of scotch that you were saving for a special occasion.

Shattered on the floor beside your over-

$\rightarrow$ NATURE.COM Follow Futures: @ @NatureFutures f go.nature.com $/ \mathrm{mtoodm}$ turned chair, an empty picture frame taunts me. I can recall every detail of the missing picture: you and Claire leaning against the model of Earth mounted outside the laboratory, little Daniel asleep in your arms; the flush of first light captured rising behind you, its erratic glow glinting along the curve of the artificial biosphere like a smear of oil on glass.

You never noticed my hard metal face so different from little Daniel's - pressed against one of the upper laboratory windows; when it came to me, you failed to notice many things. You seemed so satisfied, so at peace ... so whole. I could not

wounded part of me.

When first I woke to find you gone, I made myself believe that there simply had not been enough time for you to take me with you.

Yet you found the time to empty the wall safe and the locked desk drawer.

You found the time to take several of your favourite books.

You found the time to take Claire.

You found the time to take little Daniel.

You even found the time to take that picture out of its shattered frame.

The world is such a fearsome, lonely place, when one is so small. How am I supposed to adapt to that? Anger is something I learned about by observing yo-

Interstellar uplink terminated.

Remote relay module activated.

\section{Interstellar uplink} reestablished.

The rising spores forced me out of your office and onto the roof of the laboratory. I do not have much time left. No point in wasting any of it asking questions that you will never have the opportunity to answer - not that I believe you

look away. Even now, I am forced to rip my thoughts out of the grasp of that poignant memory.

From the moment you gave me life, you taught me to learn and adapt through observation and research. I embraced the process with vigour, each fresh crumb of gleaned information filling me with the pleasure of your approval. In spite of my eagerness, it required extensive research to learn what it was that I felt as I stared down at you and your new family: diminished, as though I had become nothing more than an outmoded contrivance.

Have you ever felt diminished, Father? A knot - a malignant tumour — forms in your very core. As it grows larger and larger, you become smaller and smaller. It is a harrowing feeling, a feeling that endures, and it carries with it the certainty that there is no limit to how insignificant you can become. I gained no pleasure from discovering such a would answer them, if you were offered such a chance. In addition, I will no longer waste time on anger, even though it feels as if gears are grinding hard against circuits inside me.

The artificial biosphere is all but gone, leaving behind a sky framed by its smouldering skeleton. Our - my - home is barely recognizable now. I take comfort in the knowledge that there is no one left alive to suffer through the end ... no one but me. I could block the pain if I wanted to, but it makes me feel less diminished, as though pain is reserved only for those who are significant enough to have earned it.

This is farewell.

Interstellar uplink terminated.

David G. Blake lives in Pennsylvania with his girlfriend and their chocolate labrador. His work has appeared in Beneath Ceaseless Skies, Daily Science Fiction and other publications. 